https://doi.org/10.18485/iipe_ru_sr.2020.ch6

\title{
RUSSIAN - SERBIAN COOPERATION IN THE SECTOR OF OIL AND GAS: PAST, PRESENT, AND POSSIBLE FUTURE
}

\begin{abstract}
Petar Stanojević, Zoran Jeftić ${ }^{1}$
Abstract: The paper provides a brief history of the Russian-Serbian cooperation in the oil and gas sector, starting with the conclusion of clearing agreements during the 1950s. Special attention is given to key events such as the construction of refineries in Novi Sad and Pancevo in 1968, and the commissioning of the gas and oil transport pipelines through which oil and gas directly arrived from the then USSR to the former Yugoslavia and Serbia from 1979 onward. An overview of jointly signed agreements and cooperation plans concluded during the difficult times of the "Yugoslav crisis" is presented, when both countries had joint plans such as the construction of the Serbia-Bulgaria gas pipeline. Emphasis is placed on the turning point in 2008 when the so-called "Energy agreement" was signed, giving Russian companies the majority ownership of NIS and the underground gas storage Banatski Dvor.

The situation in the oil and gas sector in the world is especially analysed, and trends that will have repercussions on the position of this sector in Serbia.

A concise analysis of the state of the gas, and especially the oil sector in Serbia, is given. After the failure of the "South Stream" gas pipeline project and the expected completion of the "Turkish or Balkan Stream" gas pipeline, greater development opportunities are expected in the oil than in the gas sector. The gas sector is particularly burdened by the provisions of the Third Energy Package that Serbia has implemented in its legislation and by relatively small market potential.

Considering that after the completion of the second developmental phase of the Pancevo Refinery, NIS and Serbia will have one of the most modern
\end{abstract}

\footnotetext{
${ }^{1}$ Dr. Petar Stanojević, professor at the Faculty of Security Studies, Belgrade University, e-mail: petstano45@gmail.com

Dr. Zoran Jeftić, professor at the Faculty of Security Studies, Belgrade University, e-mail: jefticz@ymail.com
} 
refineries in Europe connected to the petrochemical complex, it was concluded that further development efforts should focus on increasing oil and gas production and derivatives trading. These goals include development projects in Serbia, but also in the region, the Mediterranean and beyond, i.e., those that expand the area of operation because that is the only way to reach the necessary resources and markets of sufficient size.

To that end, the Russian and Serbian sides need joint, creative strategic solutions and an "out of the box" thinking. The advantages of Serbia's geographical position, old interstate ties and the status of an associate member of the EU, as well as the relations of the Russian Federation with certain countries, should be used to open new, cost-effective perspectives. For this purpose, several suggestions and brief descriptions of possible strategies are given. At the same time, a review of the possible geopolitical implications of such solutions is given.

Keywords: oil, gas, history, strategy, development plans, Russia, Serbia.

\section{A Brief historical review of the development of the oil and gas sector in Serbia and agreements with the Russian Federation}

Most historical data on Russian-Serbian relations in the oil and gas sector could be found on the website of PE Srbijagas (Srbijagas, 2020), the website of the Oil Industry of Serbia (NIS) (NIS a.d., 2020), and the website of the Ministry of Foreign Affairs of the Republic of Serbia (Ministarstvo Spoljnih poslova Republike Srbije, 2020), but sometimes in a form too dull and incomprehensible for the average reader. Therefore, the necessary clarifications are given below, while the additions and interpretations are the contribution of the author as a direct witness to certain events.

Based on the existing Shell's, Standard Oil's and other assets, a stateowned trading company for the trade of oil and oil derivatives was formed in 1945 (red and yellow colour in the Jugopetrol's brand were a reflection of the past). By nationalizing and purchasing already existing petroleum storages and building new ones, a network of storages was created. This was the basis for the future distribution network that has developed together with the road network and the increase in the number of motor vehicles. After the Second World War, oil was processed in refineries in 
Rijeka and Bosanski Brod. It was imported mostly from Romania, and then from the USSR.

The forerunner of today's company NIS was the Company for Oil Exploration and Production based in Zrenjanin, founded in 1949 by the decision of the Government of the Federal People's Republic of Yugoslavia. The oil exploration and production company Naftagas was founded in 1953 in accordance with the decision of the Government of the Federal People's Republic of Yugoslavia (FPRY) and the management was transferred to Novi Sad. In the early 1950s, the first gas stations were opened in this area (Wikipedia, 2020). As an oil company, Jugopetrol covered the territories of Serbia, Macedonia, and Montenegro from then until the mid-1970s, and Jugopetrol Kotor and Makpetrol later separated from it.

In 1951, the construction of a gas and oil pipeline transport system began. The section of the gas and oil transport pipeline Mokrin-KikindaElemir-Velika Greda-Pancevo was completed in 1963. The production of oil and gas from Serbian fields was constantly growing and met up to $40 \%$ of domestic needs in oil and even $100 \%$ in gas when production was at its peak.

"Oil refineries in Pancevo and Novi Sad started operating in 1968 (Wikipedia, 2020)." The technology of the USSR was used in atmospheric and vacuum distillation plants (the Institute of Nizhny Novgorod was their creator, and since then the twinning of the cities of Nizhny Novgorod and Novi Sad has originated). The technology used and the configuration of the refineries has conditioned that the highest yield of derivatives can be achieved from URALS (REB) Russian oil and Iraqi KIRKUK oil. This also shows the strategic commitment of the former SFRY to the USSR and the non-aligned countries. Only since the construction of the oil pipeline, the possibility has been created to use different sources of supply to avoid dependence on one supplier. In addition to these types of oil, high-quality Libyan oil, Iraqi BASRA, and smaller quantities of Syrian, Kazakh, and other oils were imported.

The Yugoslav oil pipeline, which via Omišalj-Rijeka stretched one branch through Sisak, Bosanski Brod to Novi Sad and Pancevo, and with the other branch towards Lendava and the Hungarian border, was put into operation in 1979. This oil pipeline could supply Hungary, and even Czechoslovakia, and was conceived as a geopolitical lever for the eventual 
reduction of the USSR's influence on Hungary and Czechoslovakia. The pipeline operated in two modes, the first was pumping oil from Russia from the direction of Slovakia and Hungary to Yugoslavia and the second was pumping from the terminal in Omišalj to Yugoslav refineries and Hungary. The Russian private oil company Yukos in the 1990s and early 2000s wanted to use the possibility of exporting Russian oil via the port of Rijeka in this direction, but the idea has never been materialized.

Since the 1950s, clearing has been used in trade with the USSR. The low value of the dollar settlement had a stimulating effect on the export of Yugoslav goods. From the USSR to Yugoslavia, oil was imported according to the clearing settlement. This was a stimulus for all Yugoslav republics because this encouraged their own exports, and they could get oil, or real value, for that. This has led to the construction of oil refineries in almost all Yugoslav republics with capacities far greater than necessary.

In 1979, the transport system of the Horgos-Batajnica gas pipeline (the "pillar" or the core part of the gas transport system of Serbia) was put into operation. This gas pipeline was built in cooperation with the USSR and Hungary. In the same year, the branch of the gas pipeline to Bosnia and Herzegovina was completed and put into operation. From then until today, only Russian gas has been imported and used in Serbia. It should be borne in mind that the production of natural gas in Serbia reached as much as 2.2 billion cubic meters, which is practically equal to today's consumption of this energy source. The abundance of gas conditioned the construction of an industry that uses gas as raw material, thus the Ammonia plant, Nitric Acid plant and CAN Pancevo (Azotara Pančevo) and the Methanol-Vinegar Combine Kikinda (Metanolskosirćetni kombinat Kikinda) were founded.

The construction of the transport gas pipeline in central Serbia began in 1980, and the construction of the distribution system in 1987.

The Oil industry of Serbia, which included the oil refineries Pancevo and Novi Sad, Jugopetrol and Naftagas promet, Naftagas, Energogas, Novi Sad gas, the Oil refinery Belgrade, FAM Krusevac and NIS Engineering, was founded in 1991 as a state company for exploration, production, refining and trading of oil and oil derivatives and natural gas. The special law that was passed for that purpose wanted to protect the crucial energy activity at the dawn of the Yugoslav wars (Croatia did the same with INA). 
During the Yugoslav wars, Russia continuously supplied gas to Serbia, including through humanitarian arrangements.

In 1995, with a special "Agreement between the Federal Government of the Federal Republic of Yugoslavia and the Government of the Russian Federation on Cooperation in the Construction of a Gas Pipeline in the Federal Republic of Yugoslavia" (Official Gazette of the FRY, 1996), the Yugorozgas company was established, and the construction of the branch Pojate-Nis transport system started. The agreement provided for the construction of an interconnection (gas pipeline) with Bulgaria. On the same occasion, the "Agreement between the Federal Government of the Federal Republic of Yugoslavia and the Government of the Russian Federation on Natural Gas Deliveries from the Russian Federation to the Federal Republic of Yugoslavia" was signed (Official Gazette of the FRY, 1996).

The Protocol between the Federal Government of the Federal Republic of Yugoslavia and the Government of the Russian Federation on oil deliveries from the Russian Federation to the Federal Republic of Yugoslavia (Official Gazette of the FRY, 1996) was signed in 1996.

The privatization of NIS by Russian oil companies, especially the PSJC Lukoil, has been negotiated almost continuously since the 1990s. Documents of various weight and content were signed, but there were no concrete results.

In 2005, works began on the underground gas storage Banatski Dvor. Sometime around this time, a joint technological solution of the Novi Sad Refinery and the Russian Academy of Sciences for the production of synthetic oil was created and installed in Nizhnekamsk, through the joint venture RANIS.

In 2005, the company NIS received the status of a joint-stock company, and PE Transnafta, PE Srbijagas, the Oil Refinery Belgrade and FAM Krusevac separate from it.

Problems related to Serbian debts for energy sources from the 1990s and Russian ones related to clearing trade were mostly resolved by the "Agreement between the Government of the Republic of Serbia and the Government of the Russian Federation on regulating the obligations of the former USSR on settlements related to trade between the former USSR and of the former SFRY "(Official Gazette, 2009) and the "Protocol between the Ministry of Finance of the Republic of Serbia, the Ministry of 
Mining and Energy of the Republic of Serbia and the Ministry of Finance of the Russian Federation, the Ministry of Economic Development and Trade of the Russian Federation on harmonization of the list of goods and services delivered for the purpose of settling the debts of the Russian Federation to the Republic of Serbia" from 24 July 2007. (Ministry of Foreign Affairs, 2007)

Certainly, the most important agreement ever signed between the two countries is the "Agreement between the Government of the Republic of Serbia and the Government of the Russian Federation on cooperation in the oil and gas industry", signed in 2008 (Government of the Republic of Serbia, 2008). The agreement included the privatization of NIS, the construction of the Banatski Dvor gas storage facility, and the construction of a gas pipeline with a capacity of not less than 10 billion cubic meters per year through the territory of Serbia. This agreement will lead to substantial changes in the oil and gas sector in Serbia.

In 2008, the Russian company Gazprom Neft became the majority shareholder of NIS in accordance with the "Purchase Agreement", with $51 \%$ of shares purchased for EUR 400 million and EUR 550 million of investment obligations, primarily in the Pancevo oil refinery and for solving environmental problems.

In 2009, a Basic Agreement on Cooperation on the "South Stream" project on the territory of Serbia was signed with the Russian company GAZPROM, and a joint Serbian-Russian company "South Stream Serbia" was established with the headquarters in Zug, Switzerland.

The agreement on the establishment of a joint venture for the Banatski Dvor underground gas storage (PSG B. Dvor) between PE "Srbijagas" and the company "GAZPROM GERMANIA" based in Novi Sad and the completion of the first phase of construction of PSG B. Dvor was signed in 2010.

In 2011 the underground gas storage in Banatski Dvor was officially put into operation.

In 2012, Serbia signed agreements on the construction of the South Stream gas pipeline and passed an appropriate law that should facilitate the construction of this strategic infrastructure facility as much as possible. The same year, representatives of the governments of Serbia and Russia signed the Agreement on Natural Gas Supply from Russia in 2012-2021, as 
a basis for signing a long-term gas supply agreement between "Gazprom" and PE "Srbijagas" (Government of the Republic of Serbia, 2013).

In 2012, the construction of the mild hydrocracking plant (MHC/DHT) was completed at the Pancevo Oil Refinery, which marked the completion of the first phase of the refinery modernization and the fulfilment of investment obligations by Gazprom Neft. In the same year, NIS began to expand in the region: in Bosnia and Herzegovina, Bulgaria, and Romania.

A Memorandum of Understanding in the field of energy efficiency, energy-saving and renewable energy sources between the Ministry of Mining and Energy of the Republic of Serbia and the Russian Energy Efficiency Agency of the Ministry of Energy of the Russian Federation was signed in 2014 (Ministry of Mining and Energy, 2014).

Works on the deep processing plant with delayed coking technology began in 2017 at the Pancevo Refinery with the aim to put the plant into operation in 2020. The same year, a contract on the construction of the thermal power plant - heating plant Pancevo was signed between the companies "TE-TO Pančevo" and the Chinese company "Shanghai Electric Group", and the corporate Development Strategy of NIS until 2025 was adopted.

In 2018, the construction of the "Turkish Stream" gas pipeline began, whose pipes were laid before the end of 2019 , and the construction of the compressor station began in 2020. The pipeline is not yet connected to the gas pipeline systems of Bulgaria and Hungary at the time of writing this paper.

Besides, it should not be forgotten that the Russian Federation is one of Serbia's strategic partners and that the "Declaration on Strategic Partnership" was signed in 2013 in Sochi (Government of the Republic of Serbia, 2013). To this should be added a free trade agreement.

All interstate cooperation is coordinated permanently, based on the "Agreement between the Federal Government of the Federal Republic of Yugoslavia and the Government of the Russian Federation on the Establishment of the Intergovernmental Yugoslav-Russian Committee for Trade, Economic and Scientific-Technical Cooperation" of 1995. This Committee meets every year. 


\section{The situation in the oil and gas sector in the world and possible tendencies}

According to the latest official data for 2018, or from the period before the pandemic KOVID-19 (British Petroleum, 2019), oil consumption in the world has increased, but slower than its production. According to the same source, natural gas consumption is growing strongly, supported by wide demand and increasing gas availability, with the help of constant expansion of liquefied natural gas (LNG).

Forecasts said that natural gas would take precedence over oil in the 2020 s as the most important energy source in the 2020s (DNV, 2019).

The result of the "oil market crisis" that occurred during the KOVID19 pandemic was that three key players in the oil market stood out, namely Russia, Saudi Arabia and the United States, which are responsible for over a third of world oil supplies.

In the first four months of 2020, there was a drastic drop in global car sales - by about one third compared to the same period in 2019. Electric cars - a key element of the transition to cleaner energy, also sold less. However, despite the crisis, their sales could reach a record share in the total car market this year.

The peak of oil demand can be reached in the next decade or by 2040 , i.e., the longer the pandemic lasts, the later. It is clear that it is impossible to rely entirely on one or a few sources of primary energy for energy security and decarbonisation, which will have to be achieved through an optimal energy mix, which is, in principle, an issue for each country. Advances in energy efficiency, new technologies and increasingly stringent environmental regulations will limit further growth in oil and gas consumption.

Demand for gasoline and diesel will grow more slowly as a result of changing consumer habits, the adoption of electric vehicles, an increase in the efficiency of internal combustion engines, but also increased mixing of biofuels. There are serious attempts to reduce the share of petroleum products in aviation and shipping. Countries with the highest fuel consumption have switched to the Euro 5 standard. Safety and environmental standards in the oil and gas sector will become increasingly demanding. The public will ask more and more questions 
and there will be fewer company secrets in this area. Without public support, it will be increasingly difficult for oil and gas companies to do business.

The International Research Group for the Conservation of Clean Air and Water in Europe (CONCAVE) shows that 21 refineries in Europe have been closed since 2009 . The need for refinery capacity is projected to fall by about $25 \%$ after 2030 . Those refineries that are more complex with the most efficient processes and that are integrated with petrochemicals have a higher chance of surviving (such is the Pancevo Refinery).

Oil and gas companies are already doing a lot in the field of decarbonisation. For example, they install wind generators on oil platforms, build solar power plants, cogeneration plants, introduce new energy, and petrochemical solutions. They want to achieve the so-called "zero carbon footprint", i.e., to conserve carbon dioxide in proportion to the amount they produce.

There will be a consolidation of buyers on the market in order to reduce the price of raw materials by increasing the volume of purchases. Companies from African countries have been doing that for years. In general, the market will soon turn completely into a customer market because the production of hydrocarbons will be higher than the demand.

\section{Present and future of the oil and gas sector in Serbia in the light of interstate cooperation between Serbia and Russia}

\section{The situation in the oil and gas sector in Serbia}

The oil market in Serbia is the so-called "an oligopoly with a dominant player." This practically means that, on the one hand, we have NIS with oil and gas production, refinery, storages and pump network (dominant player), and on the other hand, we have many smaller or larger traders with relatively limited storage capacities and $2 / 3$ of pumps. That is why every story about oil in Serbia is mostly a story about NIS. The story of gas in Serbia, similar to the previous one, is the story of Srbijagas, which is the only one that has a transport system, storage, and distribution of gas. All the others (about 36 of them) are only gas distributors, except for 
Yugorozgas, which has a transport system from Pojate, through Nis to Leskovac and distribution in Nis and Leskovac.

In general, fuel consumption in Serbia increased by $5.1 \%$ in 2019 compared to 2018, especially the consumption of diesel. This is a consequence of the redirection of European traffic to the newly built corridors 10 and partly 11, and economic growth. Gas consumption in Serbia has been growing at a rate of $2-3 \%$ per year in recent years.

In the last five years, about half a million used vehicles have been imported to Serbia. If this trend continues, the pollution we can expect in the coming years could take more human lives than the coronavirus Covid-19.

The first contracts for granting subsidies to citizens for the purchase of electric and hybrid vehicles were scheduled for signing in the middle of this year. The charging infrastructure is still modest, although the efforts are made to improve it.

The above-mentioned is confirmed by the fact that, despite the global trend of switching to electric vehicles, their mass arrival in Serbia cannot be expected soon. The situation is similar in the region. This is good news for the oilmen but not for citizens who care about the environment, clean air, and the reduction in the number of illnesses and deaths related to them.

The good news is that due to the state programs of marking and quality control, fuel smuggling has been seriously reduced, and the quality is at the prescribed level, which also affects the reduction of pollution. The state has started a program of creating obligatory oil reserves, which is improving its energy security every day.

According to the report to its investors, NIS extracted 859,000 tons of oil and 389 million cubic meters of gas from the Serbian fields in 2019 or $3 \%$ less than in 2018. In 2019, 3,373,000 tons were processed or $12 \%$ less than in the previous year (justified by the overhaul of the refinery). Sales were $3,702,000$ t or only $1 \%$ less than in 2018 . EBITDA fell by $17 \%$ and profit by $34 \%$. The financial result is modest, bearing in mind that the ore rent is at the level of only 7\% (NIS a.d., 2019).

These results are not encouraging at all if it is known that the demand for fuel, especially diesel, has increased in Serbia, i.e., NIS has lost more because the market environment was favourable. What is further striking is that the production of oil and gas has dropped almost to the level from 
before 2009, i.e., before the privatization. The results of the fracking of the existing wells were obviously short-lived, and the fate of further exploitation of Serbian oil is now in question. Reducing domestic gas production is not in favour of Serbia's energy security. The refinery operates at $70 \%$ capacity, which is below the level that provides economies of scale. A somewhat bright spot is the turnover, which at least does not lose much market share, and has expanded its activities to the region so that the company owns a network of gas stations in Serbia (323) in Romania (18), $\mathrm{BiH}$ (37) and Bulgaria (35). The situation after the coronavirus Covid-19 can only get worse.

The positive moments are that the Deep Processing and Gas Power Plant projects are coming to an end. Upon their completion, NIS will own the most modern refinery in the region and maximally valorize the gas it produces. The good news also comes from Bosnia and Herzegovina, where NIS is conducting exploration work, and from Romania, where the experimental production at 4 wells has been launched.

Regarding oil as an energy source and the oil market, Serbia must have a double goal. The first is to promote electric vehicles and renewable energy sources to reduce pollution, improve energy security and promote the use of lithium, which could be a new national treasure if it turns out that the development of batteries for electric vehicles will go in the direction of using this metal. Given that the state owns about $29 \%$ of NIS shares, its second goal must be the development and support of this company because without its support NIS will experience hard times in the transition period.

The first goal can be achieved through creative regulation through which, for example, all pumps will be obliged to upgrade the charger for electric vehicles in the next ten years (like in Germany) and to provide various financial incentives to car buyers but also manufacturers of electric cars and batteries if they are produced in Serbia.

To achieve the second goal, the state and NIS must develop a joint strategy and use all the opportunities available to them. The fact that fossil fuels will dominate the region for at least another twenty years and that many regional refineries are closed should be used as an advantage. Given that no further technological and commercial justification can be found for continuous investment in oil refining, it is obvious that the focus must be on oil exploration and production and derivatives trading. 
The state, on its part, can help the oil economy by increasing the purchase of now cheaper oil derivatives, through a system of commodity and required reserves, which would stimulate demand. In that way, it can help agriculture and other economic branches by lending these derivatives to farmers and economic organizations with the return obligation, etc.

The biggest event in the gas part of the sector will certainly be the commissioning of the "Turkish or Balkan Stream" gas pipeline. This way, cheaper gas could arrive in Serbia, but also its energy security, which is completely dependent on one gas entrance to the country, could be significantly improved. Due to the obligations on the way to joining the EU and those from the Law on Energy passed in 2014, PE Srbijagas will have to be divided by activities, into transport, distribution, and storage part. Serbia needs to build interconnections with Bulgaria and probably Romania, according to commitments already made. The storage part of the company should not worry about its fate, especially if the intentions to expand the existing gas storage and fulfil the legal obligations on the formation of "mandatory gas reserves" are realized. The transport part will probably remain in state ownership, but it will have a problem if small quantities of gas are transported through "old" gas pipelines and new interconnections because most of it will go through the "Turkish or Balkan Stream" gas pipeline. The only parts that will be relatively liquid are trade and distribution, but we should also keep in mind that the market is not large or has great development potential if we exclude the construction of gas power plants.

In the gas sphere, the possibilities for Russian-Serbian cooperation after the construction of the "Turkish or Balkan Stream" gas pipeline practically remain only in the sphere of privatization of gas distribution and construction of the gas pipeline from Leskovac to Vranje and further to the Macedonian border by Yugorozgas. Further construction of gas power plants is possible, but first, Serbia has to adopt a new energy strategy that should define the optimal mix of primary energy sources.

Due to the above-mentioned, in the following text, more attention will be paid to NIS as an oil and gas company that has a much larger "room for manoeuver" for development. 


\section{Comments on the current NIS strategy}

NIS has an elaborated strategy that covers all activities of the company (NIS a.d., 2017).

It is considered that the ideal ratio between production, refining and sales in vertically integrated oil companies, such as NIS, is $1: 1: 1$, i.e., the exact amount of oil produced is being refined and the same amount is sold through its own sales channels. The NIS strategy envisages a ratio of $1 / 3$ or $1 / 4: 1: 1$, which indicates a potentially smaller opportunity to operate stably and with maximum effects on the value chain.

The strategy in oil and gas production is primarily focused on reducing or maintaining the same level of production in Serbia, which, according to the latest reports, will apparently not be realized. There is talk of abandoning the concession in Angola, while certain effects are expected from the concessions in Romania. The company owns and procures drilling equipment that can operate in the EU. In the past, there was always a surplus of so-called service capacities, including oil drilling facilities, as evidenced by the still ongoing engagement of services in Turkmenistan.

In order to reduce the negative effects of the reduction of oil and gas production, the emphasis in the strategy is placed on refining and trade (downstream). Thus, the growth of processing is predicted from about 3.5 million tons per year to $4.2-4.4$ million tons per year. This means that the company must increase its sales outside the Serbian market because the consumption of the Serbian market is small and won't necessarily grow quickly.

Upon the completion of the Deep Processing project, the Pancevo Refinery will produce almost exclusively petroleum products with high added value, i.e., diesel, gasoline and kerosene, as well as coke, which is currently imported. The refinery is planned to supply with predominantly domestic Serbian oil, REB (Russia), and Kirkuk (Iraq).

The company currently places its products on the markets of Macedonia, Bulgaria, Romania and Bosnia and Herzegovina and to a lesser extent on some others (200-500,000t per year). It owns the storage only in Bulgaria. 
There are no indications in the strategy of a larger expansion of the sales network in the recent period, which does not fit with the goal of increasing processing in the refinery.

In energetics, the company participates in wind farm projects and the construction of a 170MW gas power plant in Pancevo. For this last project, the question is whether there is enough gas from Serbian sources or gas will be imported.

Among other projects, the company showed interest in the construction of the Pancevo (Serbia) - Timisoara (Romania) product pipeline, the construction of an oil refinery in Novi Sad, investment in Petrohemija Pancevo, exploitation of oil shale in Aleksinac, and the purchase of one of the larger gas station chains in the region. Cooperation with major international chains in the region was also discussed.

The most important potentials that NIS has, but are not included in the strategy, are:

- More gas deposits, which could be converted into gas storage facilities with a capacity of about 5 billion cubic meters. Given that $\mathrm{BiH}$, Macedonia and Greece cannot build gas storage facilities, as well as the passage of the "Turkish Stream" gas pipeline through Serbia, this possibility can be commercially effective. It should be kept in mind that the European Union has approved the money for the construction of the Itebej gas storage, which was never used.

- Large existing storage capacities for storage of oil and derivatives, but also great potential for their upgrading for the purpose of storing Serbian obligatory reserves of oil derivatives (it is considered that around 100,000 cubic meters more of storage space is needed), as well as for derivatives trading in the Danube basin. For the latter, the existing NIS location in Novi Sad is ideal.

- Bunkering of LNG on the Danube in accordance with the LNG Master Plan for Rhine-Main-Danube from 2015, which identifies opportunities for supplying Europe with LNG via the Black Sea and the Danube. On this route, traffic of LNG tankers of 1000-3000t is possible (with some maintenance works on the lower course of the Danube). These are ships that can sail both on the Black Sea and on the Danube, which means that they could be supplied with LNG somewhere on the east coast of the Black Sea. 
In order for NIS to maximize the effects of existing capacities and those planned to be built within the current strategy, at the international level it would be desirable:

- Obtaining new concessions in the Balkan region, but also beyond, preferably in the Mediterranean region (because there are logistical supply opportunities from there). Both oil and gas concessions are of interest.

- Reduction of oil import costs that can be achieved by gaining access to the Druzhba oil pipeline through Slovakia, Hungary and Croatia or by building a section of the oil pipeline from Pitesti (Romania) to Pancevo (Serbia) to enable the direct supply of oil from the Black Sea. Both Lukoil and Gazprom Neft have expressed interest in building this $170 \mathrm{~km}$ long pipeline, which would connect Serbia with the Black Sea. In addition to cheaper transport, the geopolitical aspect is also important because Serbia would not be tied exclusively to the oil pipeline that passes through Croatia.

- Increasing the export of oil derivatives to the region and beyond imposes the need for an urgent solution of logistical problems through the construction of pipelines to Romania and possibly at least to Nis in order to create logistical opportunities for exports to Romania, Bulgaria, Macedonia, and so-called Kosovo. It is also necessary to build storage for derivatives in Romania and BiH. In this way, NIS would reduce transport costs to the level to be the most competitive in these markets.

- Of the larger gas station chains in the region, the only remaining large chain that is not integrated into larger international systems is Makpetrol, Skopje, Macedonia.

- The larger international chains operating in the region are Oiltanking (Germany), Shell and OMW (Austria), so cooperation should be based on this knowledge (MOL and Hellenic are less influential players in the market).

- The existence of a concession in Africa, services in Turkmenistan, and the need for more exports do not exclude activities on other continents.

- The operation of the Russian company Zarubezhneft (Bosanski Brod) and partly Lukoil in the same markets on which NIS focuses, imposes the need for a partnership rather than a competitive relationship. This 
especially refers to the possible creation of a joint venture with Zarubezhneft, which would create the largest oil company in the region and enable the integrated operation of refineries. Geopolitics is certainly on the side of this solution because the joint company could be dominant in Serbia, Kosovo and Metohija, BiH, Slavonia, Montenegro, and Macedonia.

\section{Possible access to joint development plans}

"Three regions" Access

NIS can potentially realize its activities at the international level in "three regions":

- The regional - Balkan/Danube

- The Mediterranean - Middle Eastern

- African

The Balkan/Danube region includes activities on the possible acquisition of Makpetrol, construction of the Serbia-Romania product pipeline (Pancevo-Timisoara), product pipeline to Nis, regulation of supply through the Druzhba oil pipeline, purchase or construction of derivatives storages in neighboring countries, expansion of NIS gas station network, cooperation with regionally present international companies, acquisition of new concessions, integration with Zarubezhneft's assets and cooperation with other Russian companies present in the region, participation in infrastructure and other projects, etc. To resolve open issues in these projects, it may be better to use the status of NIS as a Serbian company that already largely operates in accordance with EU regulations. There is also an unresolved problem in the region, such as the ownership of the JANAF (Croatia-Serbia) oil pipeline, for which possible solutions from a geopolitical and security point of view should also be considered. The production of oil from oil shale near Aleksinac must be actualized to compensate for the negative effects of the decline in domestic oil production.

The Mediterranean-Middle Eastern region is interesting for two reasons. The first is to obtain new oil and gas concessions for NIS to raise the share of "own" oil and gas in the strategic mix. Synergy with the parent 
company Gazprom (Gazprom EP International B.V.) and involvement in its projects is one of the possibilities. ${ }^{2}$ Of particular interest are projects in Algeria (Gazprom, 2019), (Gazprom, 2019) and Libya (Gazprom, 2019) due to the existence of already signed contracts and concessions. NIS probably has a surplus of service resources, and light oil from these countries is very suitable, having in mind the configuration of the Pancevo Refinery and the logistical possibilities through the JANAF (RijekaPančevo) oil pipeline. Serbia, as well as Russia, has traditionally excellent relations with these countries.

The war in Syria is coming to an end and it is a question of the near future when the exploration, production, and export of oil and gas will start again. Gazprom already has certain favourable positions in Syria (OilPrice, 2020) because it signed an agreement, according to which it is responsible for the further development of Syria's energetics and energy infrastructure. NIS has the advantage of a surplus of its service potentials here, as well as a possible buyer of Syrian oil due to the proximity and logistical advantage of supply through ports in the Mediterranean.

The second reason is that more gas pipelines such as the TAP/TANAP and EAST MED will cross the Balkans in the near future (Reuters, 2019). Through these gas pipelines, gas from Azerbaijan, Israel, Cyprus and Egypt, and in the future may be from Iran and Syria, will reach European consumers. Serbia will be connected to these gas pipelines via the GreeceBulgaria and Bulgaria-Serbia interconnections. NIS is a company that, through SWAP or directly, could be a user of these new infrastructures, a buyer and distributor of Gazprom gas produced or obtained by SWAP in these regions.

The third, African region, can be included in the consideration in order to better effectuate the NIS concession in Angola through, for example, participation in the reconstruction of the only refinery in Zambia, and its supply with oil or semi-finished products. Relations between Zambia and Serbia are more than cordial, and any initiative, assistance and investment are accepted without "political" prejudices. This situation can be related in a broader context to Tanzania, for whose oil/gas resources Gazprom has shown interest (Gazprom International, 2019). It should be noted that Tanzania (the port of Dar es Salaam) and the refinery in Zambia are connected by a pipeline, which is why logical thinking is imposed on the possible use of more effects and the realization of higher-level synergies. 
The above-mentioned are just some of the ideas and possibilities that should be considered.

\section{"Judo grip" approach}

NIS, as a company registered in Serbia, a country that is an associate member of the EU, should use its position to insist on the implementation of the "Third Energy Package". This currently applies to the supply of oil through the JANAF and the Druzhba.

If gas production starts at Gazprom's concessions in Algeria or Libya, gas can currently be delivered to other markets only through the pipeline that connects Algeria and Libya with Spain and Italy. NIS, as a company registered in an associated EU member state, which is both a buyer (e.g., for the needs of the gas power plant in Pancevo) and a registered gas trader, no one will be able to deny access to the "pipe", which is not certain for Gazprom or its $100 \%$ subsidiaries.

This advantage NIS can also use with the TAP/TANAP gas pipeline for possible gas supply from Gazprom's Iranian concessions or the EAST MED gas pipeline for possible gas supply from Syria.

Similar logic is applied to the previously planned gas pipeline from Libya to Italy, which Gazprom was supposed to implement in cooperation with the Italian ENI (New York Times, 2008).

Practically, a "judo grip" 3 means the use of EU rules for the possible realization of the goals of NIS and Gazprom, whereas the both companies represent the indispensable factors.

\section{Concluding remarks}

Cooperation in the oil and gas sector between Russia and Serbia will begin with the conclusion of clearing agreements during the 1950s. It intensified with the construction of refineries in Novi Sad and Pancevo, and especially intensified in 1979 after the commissioning of the transport gas and oil pipelines through which oil and gas directly arrived from the then USSR to the former Yugoslavia and Serbia. During the 1990s, Russia continuously supplied gas to Serbia, and most of the time, oil through interstate and humanitarian arrangements. 
Even in those difficult times, both countries have joint plans, such as the construction of the Serbia-Bulgaria gas pipeline.

The turning point happened in 2008 when the so-called "Energy agreement" was signed. According to this agreement, Russian companies became the owners of NIS and the underground gas storage Banatski Dvor. After the failure of the "South Stream" gas pipeline project, the completion of the "Turkish or Balkan Stream" gas pipeline is expected, which should put Serbia on the gas map of Europe.

Given that after the completion of the second phase of development of the Pancevo Refinery, NIS and Serbia will have one of the most modern refineries in Europe, related to the petrochemical complex, further development efforts should focus on increasing oil and gas production and derivatives trading. These goals include development projects in Serbia, but also in the region, the Mediterranean and beyond, i.e., those that expand the area of operation because only in this way can the necessary resources and markets of sufficient size be reached.

To that end, the Russian and Serbian sides need joint, creative strategic solutions and an "out of the box" thinking. The advantages of Serbia's geographical position, old interstate ties and the status of an associate member of the EU, as well as the relations of the Russian Federation with certain countries, should be used in order to open new, cost-effective perspectives.

\section{References}

Bloomeberg. (2019). https://www.bloomberg.com/research/stocks/ private/snapshot.asp?privcapId $=46740818$.

British Petroleum. (2019). BP Statistical Review. Preuzeto sa https:// www.bp.com/content/dam/bp/business-sites/en/global/ corporate /pdfs/energy-economics/statistical-review/bp-stats-review-2019full-report.pdf.

DNV. (2019). DNV energy transition Outlook 2019. - Oil and gas. Preuzeto sa https://eto.dnvgl.com/2019.

Gazprom. (2019). http://www.gazprom-international.com/en/newsmedia/articles/gazprom-international-completes-exploration-algeria. 
Gazprom. (2019). http://www.gazprom-international.com/en/ operations /country/libya.

Gazprom. (2019). http://www.gazprom.com/projects/algeria/.

Gazprom International. (2019). http://www.gazprom-international. com/en/news-media/articles/new-minister-energy-tanzania.

Ministarstvo Inostranih poslova. (2007). Protokol izmedju Ministarstva finansija Republike Srbije, Ministarstva rudarstva i Energetike Republike Srbije i Ministarstva finansija Ruske Federacije, Ministarstva Ekonomskog razvoja i trgovine Ruske Federacije o..... Arhiva MIP Arh. broj 9071/07 D-71/07.

Ministarstvo rudarstva i energetike. (2014). Memorandum o razumevanju u oblasti energetske efikasnosti, uštede energije i obnovljiivih izvora energije izmedju Ministarstva rudarstva i energetike Republike Srbije i Ruske agencije za energetsku efikasnost Ministarstva energetike Ruske Federacije. Arhiva MIP 9107/14 D-107/14.

Ministarstvo Spoljnih poslova Republike Srbije. (2020). http://www. mfa.gov.rs/sr/index.php/spoljna-politika/bilateralni-odnosi/117bilateralni-odnosi/11519-ruska-federacija?lang=cyr.

New York Times. (2008). https://www.nytimes.com/2008/04/09/ business/worldbusiness/09pipeline-web.html.

NIS a.d. (2017). Integrisana korporativna strategija NIS. Preuzeto sa https://www.nis.eu/o-nama/integrisana-korporativna-strategija-nisa-do-2025.

NIS a.d. (2019). Izveštaj investitorima. Preuzeto sa http://irnis.eu/ fileadmin/template/nis/pdf/Reporting/Presentations/Serbian/Pres entation_Results_2019_ser_final.pdf.

NIS a.d. (2020). https://www.nis.eu/istorija/.

OilPrice. (2020). https://oilprice.com/Energy/Energy-General/WhatHappens-To-Syrian-Oil-Post-Civil-War.html.

Reuters. (2019). https://www.reuters.com/article/us-ceraweek-energyisrael/israel-expects-decision-on-east-med-gas-pipeline-to-europein-2019-idUSKCN1GK2OI.

Službeni glasnik. (2009). „Sporazumom izmedju Vlade Republike Srbije i Vlade Ruske Federacije o regulisanju obaveza bivseg SSSR po 
obracunima vezanim za robni promet izmedju bivseg SSSR i bivse SFRJ . br. 42.

Službeni list SRJ. (1996). "Sporazumom izmedju Savezne Vlade Savezne Republike Jugoslavije i Vlade Ruske Federacije o saradnji u izgradnji gasovoda na teritoriji Savezne Republike Jugoslavije". br. 4. Belgade, Serbia.

Srbijagas. (2020). https://www.srbijagas.com/?page_id=2626\&script =lat. Vlada Republike Srbije . (2013). “Sporazum o isporukama prirodnog gasa iz Rusije do 2021. godine, kao osnove za potpisivanje ugovora o dugoročnim isporukama gasa između „Gasproma“ i „Srbijagasa“. Službeni glasnik RS br. 3.

Vlada Republike Srbije. (2008). "Sporazum izmedju Vlade Republike Srbije i Vlade Ruske Federacije o saradnji u oblasti naftne i gasne privrede". Službeni glasnik RS, br. 83.

Vlada Republike Srbije. (2013). „Deklaracija o strateškom partnerstvu“. MIP Arh. broj 9077/13 D-77/13.

Vlada Savezne Republike Jugoslavije. (1995). „Sporazum Savezne vlade Savezne Republike Jugoslavije i Vlade Ruske Federacije o formiranju Medjuvladinog jugoslovensko-ruskog komiteta za trgovinu, ekonomsku i naucno-tehnicku saradnju". Službeni list SRJ br. 1/95.

Wikipedia. (2020). https://en.wikipedia.org/wiki/Naftna_Industrija_Srbije. 